\title{
Pulmonary Antioxidant Enzyme Maturation in the Fetal and Neonatal Rat. II. The Influence of Maternal Iron Supplements upon Fetal Lung Catalase Activity
}

\author{
A. KEITH TANSWELL AND BRUCE A. FREEMAN \\ Department of Paediatrics, University of Western Ontario, London, Canada and Department of Medicine, \\ Duke University Medical Center, Durham, North Carolina 27710
}

\section{Summary}

It was obsecsved that the lung catalase activity of premature (day 21 of gestation; term $=22$ days) rat pups is affected by maternal iron intake. Pups from control dams receiving Purina Lab Chow and water ad libitum have only $50 \%$ of the lung catalase activity of pups from dams who received $1 \mathrm{mg} / \mathrm{kg}$ parenteral iron dextran daily from day 7 to day 20 of gestation. Other oxygen-protective enzymes, copper-zinc and manganese superoxide dismutase, glutathione peroxidase, and glucose-6phosphate dehydrogenase, were unaffected by maternal iron supplements.

\section{Abbreviations}

CuZn SOD, copper zinc superoxide dismutase

CAT, catalase

G-6-PD, glucose-6-phosphate dehydrogenase

GPx, glutathione peroxidase

Mn SOD, manganese superoxide dismutase

HBSS, Hanks' balanced salt solution

Undernutrition is reported to enhance pulmonary oxygen toxicity (10). One potential contributing factor is a loss of metalloprotein antioxidant enzymes activities upon metal depletion. This has been reported with copper (4) for CuZn SOD, with manganese (6) for Mn SOD, with iron and selenium (18) for GPx, and with iron (20) for CAT.

We have previously reported that the specific activity of lung catalase of gravid female rats fed Purina Lab Chow ad libitum declined with gestation (13). The fetuses of these animals demonstrated gestation-dependent increases in specific activity of CuZn SOD, Mn SOD, GPx, and G-6-PD in lung between day 18 and day 22 (term) of gestation (24). The specific activity of fetal lung CAT, however, increased between days 18 and 20 of gestation, but showed no significant increase between day 20 and term (24). Since the fall in maternal lung CAT activity towards the end of gestation was reversed by parenteral iron supplements, it is possible that the blunted increase in fetal lung catalase reflected limited iron transport across the placenta.

In this report, we examine the effect of maternal iron supplementation on fetal lung growth, and on the specific activity of oxygen-protective enzymes of fetal rats sacrificed prematurely on day 21 of gestation. Reported values have been corrected for

Received June 13, 1983; accepted February 7, 1984

Address correspondence to Dr. A. K. Tanswell, Research Institute, St. Joseph's Hospital, 268 Grosvenor Street, London, Ontario N6A 4V2, Canada.

Supported by grants MA 7867 from the Medical Research Council of Canada (A. K. T.), and HL-29784 from the National Institutes of Health (B. A. F.). enzyme activity contributed by contaminating blood by a modification of the method described by Cross et al. (5), using homologous blood supplements.

\section{MATERIALS AND METHODS}

Female Sprague-Dawley white rats of $275-300 \mathrm{~g}$ (Charles River Inc., St. Constant, Quebec) were mated with male hooded rats and delivered to our animal quarters the following day. From day 7 to day 20 of gestation, the gravid rats were injected intramuscularly with either $1 \mathrm{mg} / \mathrm{kg} /$ day of iron dextran in isotonic saline or isotonic saline alone, or received no injections. On day 21 of gestation (term $=22$ days), the animals were sacrificed by excess chloroform anesthesia; the fetuses were decapitated in utero to prevent respiration and immediately removed from the uterus. Each fetus was weighed and the carcasses were placed in HBSS at $4^{\circ} \mathrm{C}$. The chest cage was opened from diaphragm to neck; then the heart and lungs were removed en bloc and kept in HBSS at $4^{\circ} \mathrm{C}$. The heart and major airways were dissected off and the lungs from each fetus were washed with HBSS, blotted dry, and weighed. The lungs from each litter were then pooled, minced, and homogenized in $5 \mathrm{ml} 50 \mathrm{mM}$ potassium phosphate, $0.1 \mathrm{mM}$ EDTA, pH 7.8 for $30 \mathrm{~s}$ at $4^{\circ} \mathrm{C}$ with a Polytron (Brinkmann Instruments, Inc., Westbury, NY). The homogenates were centrifuged at $1000 \times g \times 10 \mathrm{~min}$ to remove fibrous material and the supernatants were stored at $-70^{\circ} \mathrm{C}$ prior to analysis. Preliminary observations showed no loss of enzyme activity with centrifugation or a single freeze-thaw of homogenates.

Protein content was estimated by the Lowry method (19), and DNA was estimated fluorimetrically (7). CAT (EC 1.11.1.6.) was measured as described by Bergmeyer (2), GPx (EC 1.11.1.9.) as described by Beutler (3), and G-6-PD (EC 1.1.1.49.), CuZn SOD, and Mn SOD (EC 1.15.1.1.) as described by Hayatdavoudi et al. (14). A number of homogenates from each group also had CAT estimations performed in the presence of $10^{-9}$ to $10^{-6} \mathrm{M}$ iron as ferric nitrate $\left(\mathrm{Fe}\left(\mathrm{NO}_{3}\right)_{3} \cdot 9 \mathrm{H}_{2} \mathrm{O}\right)$.

A separate group of day 21 fetuses were sacrificed and decapitated, and blood was collected from the neck vessels by gravity drainage. Aliquots of this blood were diluted $1: 1000$ with $0.1 \mathrm{M}$ Tris- $\mathrm{HCl}, 1 \%$ Triton $\mathrm{X}-100, \mathrm{pH} \mathrm{7.0,} \mathrm{and} \mathrm{sonicated} \mathrm{for} 15 \mathrm{~s}$ at $4^{\circ} \mathrm{C}$. The absorbance of $1 \mathrm{ml}$ of fetal blood lysate was recorded from 350 to $650 \mathrm{~nm}$ before and after the addition of $100 \mu \mathrm{l}$ of $0.1 \mathrm{M} \mathrm{NaOH}, 0.1 \mathrm{M} \mathrm{Na}_{2} \mathrm{~S}_{2} \mathrm{O}_{4}$, as described by Cross et al. (5) in a Gilford 252 spectrophotometer (Gilford Instruments, Oberlin, $\mathrm{OH})$ with a Beckman DU optical system (Beckman Instruments, Fullerton, CA).

Aliquots $(5,10,20,30$, or $40 \mu \mathrm{l})$ of the $1: 1000$ blood sonicate were added to $100 \mu \mathrm{l}$ lung homogenate for each litter and made up to $1000-\mu$ l final volume with $0.1 \mathrm{M}$ Tris- $\mathrm{HCl}, 1 \%$ Triton $\mathrm{X}$ - 
$100, \mathrm{pH} 7.0$, sonicated for $15 \mathrm{~s}$ on ice, and then centrifuged at $11,000 \times g$ for $10 \mathrm{~min}$. The "dithionite index" for each sample was calculated as described by Cross et al. (5), except that the wavelength used was $405 \mathrm{~nm}$, by the formula: dithionite index $=A_{405}-\left(1.1 \times D T A_{405}\right)$ where $D T A_{405}$ represents the absorbance in the presence of $100 \mu \mathrm{l} 0.1 \mathrm{M} \mathrm{NaOH}, 0.1 \mathrm{M} \mathrm{Na}_{2} \mathrm{~S}_{2} \mathrm{O}_{4}$ and the factor of 1.1 corrects for dilution. The dithionite index obtained by addition of blood sonicate was plotted for each sample and found to be indicative of successively increasing blood contamination. From this, the original blood contamination in the sample could be calculated by extrapolation from blood-contaminated dithionite index plots.

Aliquots of blood were also examined for CAT, CuZn SOD, Mn SOD, G-6-PD, and GPx activity and, from the previous calculations of blood contamination, it was possible to correct each lung enzyme specific activity for enzyme activity due to blood contamination.

All results are presented as means \pm SEM unless otherwise stated, and statistical comparisons were made by analysis of

Table 1. Basic parameters of study groups

\begin{tabular}{lcc} 
& Control & +Iron \\
\hline No. litters & 9 & 7 \\
Pups/litters & $13 \pm 1$ & $12 \pm 1$ \\
Body weight/pup (g) & $5.2 \pm 0.1$ & $5.3 \pm 0.2$ \\
Lung weight/pup (mg) & $133 \pm 3$ & $134 \pm 8$ \\
Body weight/lung weight & $39.1 \pm 0.7$ & $39.7 \pm 2.2$ \\
$\quad$ ratio & & \\
Lung protein (mg/pup) & $4.9 \pm 0.2$ & $4.9 \pm 0.3$ \\
Lung DNA ( $\mu$ g/pup) & $115 \pm 16$ & $103 \pm 15$ \\
Protein/DNA ratio & $48 \pm 6$ & $51 \pm 6$ \\
Blood contamination & $7.1 \pm 1.8$ & $9.5 \pm 1.9$ \\
$\quad(\mu \mathrm{l} / \mathrm{g})$ & & \\
\hline
\end{tabular}

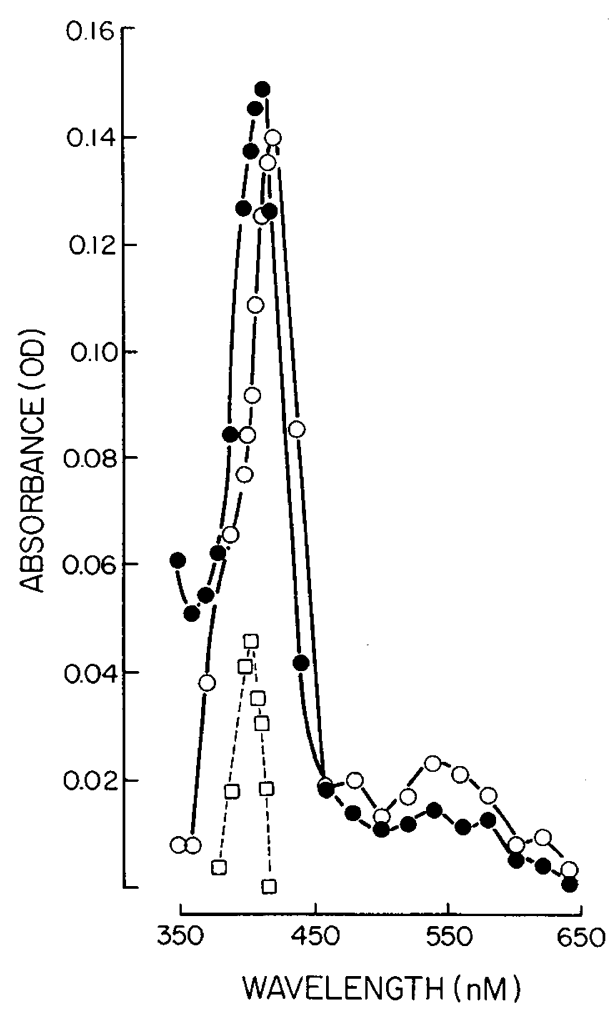

Fig. 1. The absorption spectra of 1:1000 day 21 rat fetal blood sonicate before $(\Theta)$ and after $(O)$ the addition of dithionite. The peak at 405 $\mathrm{nm}(\square)$ is the maximum of the difference of the two spectra and forms the basis of the dithionite-index.

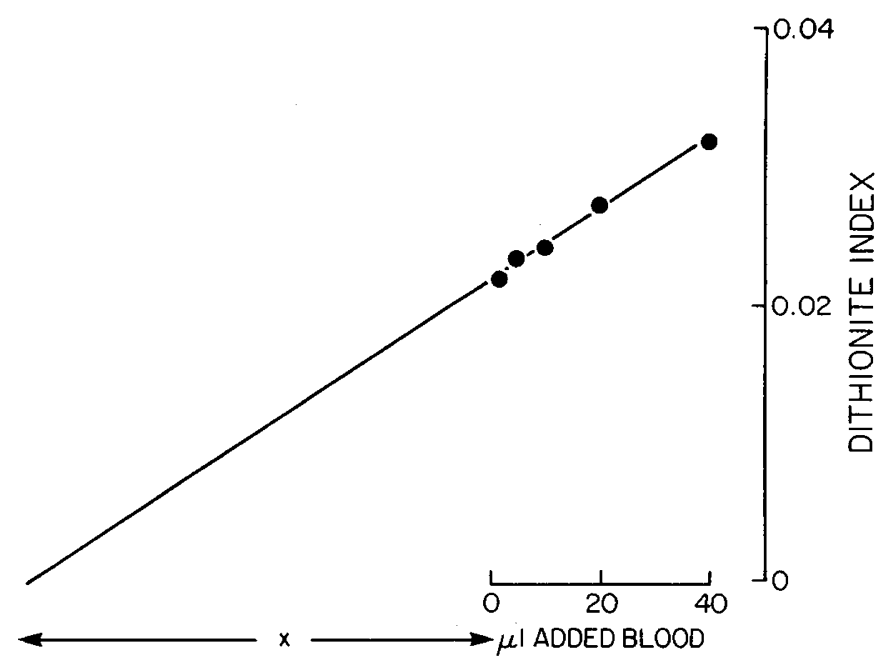

Fig. 2. Measurement of lung homogenate blood contamination. The line connecting the dithionite indices after the addition of $5,10,20,30$, or $40 \mu \mathrm{l}$ of $1: 1000$ whole blood sonicate to fetal lung homogenate has been extrapolated to the baseline. The distance from this intercept to the zero point of the baseline $(x)$ represents the absolute value of the contamination of the diluted lung homogenate with blood.

Table 2. Per cent contribution of blood to lung homogenate antioxidant enzyme activity*

\begin{tabular}{lrccccc}
\hline \multicolumn{1}{c}{ Group } & $n$ & CuZn & Mn & & & \\
\hline Control & 9 & $4.6 \pm 1.1$ & $<1$ & $4.5 \pm 1.4$ & $3.3 \pm 0.7$ & $20.1 \pm 4.9$ \\
+Iron & 7 & $4.7 \pm 1.1$ & $<1$ & $3.9 \pm 1.0$ & $3.6 \pm 0.7$ & $22.0 \pm 9.3$ \\
Combined & 16 & $4.7 \pm 0.8$ & $<1$ & $4.2 \pm 0.9$ & $3.4 \pm 0.5$ & $20.9 \pm 6.3$ \\
$\quad$ groups & & $(4.3)$ & & $(31.0)$ & $(3.6)$ & $(6.1)$ \\
\hline
\end{tabular}

* Values in parentheses are calculated from Cross et al. (5) for perfused adult lung homogenates.

variance. The basic parameters, and enzyme activities, of the saline-injected and noninjected control groups showed no significant differences $(p>0.05)$ and have been combined as a single control group.

\section{RESULTS}

The values for fetal lung weight, body weight, lung protein, lung DNA, and blood contamination are shown in Table 1. Values for fetuses of iron-injected mothers are not significantly different $(p>0.05)$ from those of controls.

The absorbance of fetal blood lysate from 350 to $650 \mathrm{~nm}$ is shown in Figure 1 before and after dithionite reduction (corrected for dilution). The absorption maximum which occurs at $405 \mathrm{~nm}$ in the spectral difference forms the basis of the dithionite index. In Figure 2, the effect of addition of $5,10,20,30$, or $40 \mu \mathrm{l}$ of $1: 1000$ blood lysate on the dithionite index of aliquots of a lung homogenate is shown. Extrapolation of the plot line to zero generates a value of $x$, from which blood contamination can be directly calculated. Contamination was not significantly different for the control or treated groups.

Values for the contribution of blood contamination to enzyme activities are shown in Table 2 and compared with values for average perfused adult rat lung homogenates, reported by Cross et al. (5). Values for lung enzyme activities in each of the groups, after correction for contamination with blood, are shown in Table 3 where values are expressed as U/pup, U/g lung wet weight, $\mathrm{U} / \mathrm{mg}$ protein, and $\mathrm{U} / \mathrm{mg}$ DNA. Only lung CAT activity was significantly different between iron-supplemented and control groups $\left(V_{1}=1, V_{2}=14: \mathrm{U} / \operatorname{pup} F=5.502, p=0.034 ; \mathrm{U} / \mathrm{g}\right.$ 
Table 3. Influence of maternal iron supplementation on fetal lung antioxidant enzyme activity*

\begin{tabular}{|c|c|c|c|c|c|c|}
\hline Enzyme & Group & $n$ & U/pup & $\begin{array}{c}\mathrm{U} / \mathrm{g} \text { wet } \\
\text { weight }\end{array}$ & $\mathrm{U} / \mathrm{mg}$ protein & $\mathrm{U} / \mathrm{mg} \mathrm{DNA}$ \\
\hline \multirow[t]{2}{*}{ CuZn SOD } & Control & 9 & $0.70 \pm 0.07$ & $5.33 \pm 0.56$ & $0.14 \pm 0.02$ & $6.92 \pm 1.26$ \\
\hline & + Iron & 7 & $0.76 \pm 0.04$ & $5.84 \pm 0.48$ & $0.16 \pm 0.04$ & $7.99 \pm 0.91$ \\
\hline \multirow[t]{2}{*}{ Mn SOD } & Control & 9 & $27 \pm 5$ & $205 \pm 34$ & $5.78 \pm 1.01$ & $266 \pm 39$ \\
\hline & + Iron & 7 & $25 \pm 2$ & $189 \pm 19$ & $5.12 \pm 0.34$ & $238 \pm 16$ \\
\hline \multirow{2}{*}{ Catalase } & Control & 9 & $93 \pm 10$ & $706 \pm 72$ & $19.3 \pm 2.1$ & $966 \pm 184$ \\
\hline & + Iron & 7 & $186 \pm 44 \dagger$ & $1359 \pm 273 \ddagger$ & $38.0 \pm 8.0 \dagger$ & $2024 \pm 589$ \\
\hline \multirow[t]{2}{*}{ GPx } & Control & 9 & $0.39 \pm 0.06$ & $2.88 \pm 0.42$ & $0.079 \pm 0.011$ & $23.87 \pm 5.63$ \\
\hline & + Iron & 7 & $0.47 \pm 0.04$ & $3.57 \pm 0.37$ & $0.096 \pm 0.003$ & $33.13 \pm 9.44$ \\
\hline \multirow{2}{*}{ G-6-PD } & Control & 9 & $21.1 \pm 4.3$ & $159 \pm 33$ & $4.4 \pm 0.9$ & $208 \pm 6$ \\
\hline & + Iron & 7 & $29.4 \pm 8.5$ & $221 \pm 63$ & $5.7 \pm 1.6$ & $311 \pm 10$ \\
\hline
\end{tabular}

${ }^{*} n$, number of litters studied. Data are expressed as $U$ enzyme activity, except for G-6-PD expressed as mU enzyme activity.

$\dagger p=0.03$.

$\ddagger p=0.02$.

lung wet weight $F=6.735, p=0.021 ; \mathrm{U} / \mathrm{mg}$ protein $F=6.097$, $p=0.027$ ). While the mean CAT activity $\mathrm{U} / \mathrm{mg}$ DNA was also double that of the control group, statistical significance was not attained $(F=3.616, p=0.078)$. The addition of iron as $10^{-9}$ to $10^{-6} \mathrm{M} \mathrm{Fe}\left(\mathrm{NO}_{3}\right)_{3} \cdot 9 \mathrm{H}_{2} \mathrm{O}$ had no effect on CAT activity in lung homogenates of either control or study groups.

\section{DISCUSSION}

No differences were seen in body or lung weight, or lung protein and DNA content, between pups of dams fed normal diets and those receiving parenteral iron. While iron-depleted gravid rats have been reported to show retarded early fetal development (22), they show no difference in term pup weight from dams fed high iron, low iron, or control diets $(1,17)$.

Cross et al. (5) reported a mean blood contamination of perfused adult lung homogenates of $20 \mu \mathrm{l}$ which, if we assume an average lung weight of $1.1 \mathrm{~g}$, represents $18 \mu \mathrm{l} / \mathrm{g}$ lung wet weight. The mean contamination of fetal lung homogenates with blood was less at $8.1 \pm 1.3 \mu \mathrm{l} / \mathrm{g}$ lung wet weight. Blood contamination of fetal lung homogenates does increase with gestational age (24), as would be expected with a developing pulmonary vascular bed. Even at term, this may be expected to be less than adult values, even after perfusion, since only $\sim 7 \%$ of cardiac output perfuses the fetal lungs in utero (21). The reason for the disparity between the observed absorbance peak at $415 \mathrm{~nm}$ reported by Cross et al. (5) and our maximum of $405 \mathrm{~nm}$ when calculating the dithionite index is not immediately apparent, but may reflect differences in spectrophotometer calibration or, more likely, in the peak absorbances of fetal and adult hemoglobin. When we examined adult blood, there was a widening and flattening of the spectral difference peak.

Loss of iron-dependent tissue enzyme activity with iron deficiency is well recognized (22), and presumably explains the loss of lung catalase activity observed in gravid rats (13) that have reduced plasma and liver ferritin concentrations (1). A reduction of CAT activity in erythrocytes and liver catalase of iron-deficient rats has been reported (18). The CAT deficiency or iron-deficient erythrocytes is reversible (20), and we have observed (25) that lung cells cultured in an iron-free medium become reversibly acatalasic. This loss of enzyme activity is probably not due to inavailability of inorganic iron acting as a cofactor, since iron addition did not increase the specific activity of catalase. Furthermore, inorganic iron cannot be expected to reactivate or increase catalase activity per se, since the iron must first be inserted enzymatically to form a heme during catalase formation. The reduced activity could be due to a deficiency of a more complex iron compound (e.g., ferritin) acting as a cofactor, or reduced synthesis of catalase apoprotein. It is unfortunate that blood from the pups of iron-supplemented dams was not examined for CAT activity, but even if the CAT activity of the red cells doubled, as might be expected (18), this would only account for $<5 \%$ of the observed increase.

In vitro observations have demonstrated enhanced hydrogen peroxide production by hyperoxic lung tissue $(12,26)$. Under normoxic conditions, CAT activity may not be essential since GPx can efficiently catalyze low concentrations of hydrogen peroxide (9). However, CAT activity is important during enhanced rates of cellular hydrogen peroxide production (15), and in vivo hyperoxia studies have shown an increase in lung CAT activity $(8,28)$. While anticipated iron deficiency in human pregnancy may be countered by routine use of iron supplements in clinical practice (16), a prematurely born infant may rapidly deplete limited iron reserves (27) at a time when high oxygen concentrations are administered for pulmonary immaturity. We speculate that any resultant loss of CAT activity could enhance oxygen toxicity, and that this may be reversible with iron supplements. Iron supplementation may also potentiate hydroxyl radical production (12) from hydrogen peroxide and superoxide, or other endogenous reductants, and thus increase oxygen toxicity. The positive or negative effects of iron supplementation should be studied in prematurely delivered animals, exposed to hyperoxia, before human trials are considered.

\section{REFERENCES}

1. Anaokar SG, Garry PJ 1981 Effects of maternal iron nutrition during lactation on milk iron and rat neonatal iron status. Am J Clin Nutr 34:1505

2. Bergmeyer HU 1955 Zur messung nov Katalase-aktivatäten. Biochem Z 327:255

3. Beutler E (ed) 1975 Glutathione peroxidase. In: Red Cell Metabolism. Grune and Stratton, New York, pp 71-73

4. Bohnenkamp W, Weser U $19772 \mathrm{Cu}, 2 \mathrm{Zn}$-superoxide dismutase in copper depleted rats. In: Michelson AM, McCord JM, Fridovich I (eds) Superoxide and Superoxide Dismutases. Academic Press, New York, pp 387-394

5. Cross CE, Watanabe TT, Hasegawa GK, Goralnik GN, Roertgen KE, Kaizu T, Reiser KM, Gorin AB, Last JA 1979 Biochemical assays in lung homogenates: artifacts caused by trapped blood after perfusion. Toxicol Appl Pharmacol 48:99

6. De Rosa G, Keen CL, Leach RM, Hurley LS 1980 Regulation of superoxide dismutase activity by dietary manganese. J Nutr 110:795

7. Erwin BG, Stoscheik CM, Florini JR 1981 A rapid fluorimetric method for the estimation of DNA in cultured cells. Anal Biochem 110:291

8. Frank L, Autor AP, Roberts RJ 1979 Oxygen toxicity in neonatal and adult animals of various species. J Appl Physiol 45:699

9. Frank L, Massaro D 1980 Oxygen toxicity. Am J Med 69:117

10. Frank L, Groseclose E 1982 Oxygen toxicity in newborn rats: the adverse effects of undernutrition. J Appl Physiol 53:1248

11. Freeman BA, Topolosky MK, Crapo JD 1982 Hyperoxia increases oxygen radical production in rat lung homogenates. Arch Biochem Biophys 216:477

12. Freeman BA, Crapo JD Free radicals and tissue injury. Lab Invest $47: 412$

13. Freeman BA, Tanswell AK 1982 Lung catalase deficiency in pregnant rats increases susceptibility to toxicity of $60 \%$ oxygen. Am Rev Respir Dis 125:228 (abstr)

14. Hayatdavoudi G, O'Neil JJ, Barry BE, Freeman BA, Crapo JD 1981 Pulmonary injury to rats following continuous exposure to $60 \% \mathrm{O}_{2}$ for 7 days. $\mathrm{J} \mathrm{Appl}$ Physiol 51:1220

15. Jones DP 1981 Intracellular catalase function. Analysis of the catalytic activity by product formation in isolated liver cells. Arch Biochem Biophys 214:806 
16. Kitay DZ, Harbort RA 1975 Iron and folic acid deficiency in pregnancy. Clin Perinatol 2:255

17. Kochanowski BA, Sherman AR 1982 Cellular growth in iron-deficient rat pups. Growth 46:126

18. Lee YH, Layman DK, Bell RA 1981 Glutathione peroxidase activity in irondeficient rats. J Nutr 111:194

19. Lowry OH, Rosebrough NJ, Farr AL, Randall RJ 1951 Protein measurement with the Folin phenol reagent. J Biol Chem 193:265

20. Macdougall LG 1972 Red cell metabolism in iron deficiency anemia. III. The relationship between glutathione peroxidase, catalase, serum vitamin $\mathrm{E}$, and susceptibility of iron-deficient red cells to oxidative hemolysis. J Pediatr 80:775

21. Rudolph AM, Heymann MA 1974 Fetal and neonatal circulation and respiration. Annu Rev Physiol 36:187

22. Shepard TH, Mackler B, Finch CA 1980 Reproductive studies in the iron- deficient rat. Teratology 22:329

23. Siimes MA, Refino C, Dallman PR 1980 Manifestations of iron deficiency at various levels of dietary iron intake. Am J Clin Nutr 33:570

24. Tanswell AK, Freeman BA 1984 Pulmonary antioxidant enzyme maturation in the fetal and neonatal rat. I. Developmental profiles. Pediatr Res 18:584

25. Tanswell AK, Freeman BA 1984 Differentiation-arrested rat fetal lung in primary monolayer cell culture. III. Antioxidant enzyme activity. Exp Lung Res, in press

26. Turrens JF, Freeman BA, Crapo JD 1982 Hyperoxia increases $\mathrm{H}_{2} \mathrm{O}_{2}$ release by lung mitochondria and microsomes. Arch Biochem Biophys 217:411

27. Widdowson EM 1974 Nutrition. In: Davis JA, Dobbing J (eds) Scientific Foundations of Paediatrics. Heinemann, London, pp 44-55

28. Yam J, Frank L, Roberts RJ 1978 Oxygen toxicity: comparison of lung biochemical responses in neonatal and adult rats. Pediatr Res 12:115

\title{
Cardiovascular Changes in Group B Streptococcal Sepsis in the Piglet: Response to Indomethacin and Relationship to Prostacyclin and Thromboxane $\mathbf{A}_{2}$
}

\author{
BEATRIZ RUNKLE, RONALD N. GOLDBERG, MURRAY M. STREITFELD, MARTIN R. CLARK, \\ ELENA BURON, EMMALEE S. SETZER, AND EDUARDO BANCALARI
}

\begin{abstract}
Department of Pediatrics (Division of Neonatology) [B.R., R.N.G., El.B., E.S.S., E.B.] and Departments of Microbiology [M.M.S.] and Obstetrics and Gynecology [M.R.C.], University of Miami School of Medicine, Miami, Florida 33101
\end{abstract}

\section{Summary}

Seventeen piglets were infected with a continuous intravenous infusion of live group B $\beta$-hemolytic streptococci (GBS). Hemodynamic changes were recorded, and blood samples were drawn for measurement of thromboxane $B_{2}\left(T_{x B}\right)$ (stable metabolite of thromboxane $A_{2}$ ) and 6-keto-PGF ${ }_{1 \alpha}$ (stable metabolite of prostacyclin). Control animals $(n=9)$ received only bacteria, while treatment animals $(n=8)$ received indomethacin, $3 \mathrm{mg} / \mathrm{kg} \mathrm{IV}$, $15 \mathrm{~min}$ after the start of the bacterial infusion. Control animals responded to the bacteria within $15 \mathrm{~min}$ with marked elevation in mean pulmonary artery pressure $(\overline{\mathrm{Ppa}})$ from $15 \pm 8$ to $39 \pm 6$ $\mathrm{mm} \mathrm{Hg}$ and decline in $\mathrm{PaO}_{2}$ from $80 \pm 11$ to $51 \pm 6 \mathrm{~mm} \mathrm{Hg}$ and cardiac output $(\mathrm{CO})$ from $0.24 \pm 0.07$ to $0.13 \pm 0.07$ liters/min/ kg. Mean arterial blood pressure (AoP) significantly decreased from baseline value of $95 \pm 13$ to $51 \pm 32 \mathrm{~mm} \mathrm{Hg}$ by $180 \mathrm{~min}$. In animals treated with indomethacin, these changes were reversed or significantly attenuated. The hemodynamic changes were associated temporally with elevations in plasma concentrations of $\mathrm{TxB}_{2}$ or $6-\mathrm{keto}-\mathrm{PGF}_{1 \alpha}$. In the first $60 \mathrm{~min}, \mathrm{TxB}_{2}$ levels in both groups correlated with Ppa $(r=0.72, p<0.001)$ and

Received August 4, 1983; accepted February 7, 1984

Address correspondence to Ronald N. Goldberg, M.D., Department of Pediatrics (R-131), University of Miami School of Medicine, P.O. Box 016960, Miami, FL 33101 .

This work was supported in part by National Institute of Child Health and Human Development Grants 1 ROI HDI4940-03 and 5 RO1 HL25023-03, March of Dimes Grant 6-303, United Cerebral Palsy Research and Educational Foundation Sydney Farber Memorial Research Award R-310-80, and Project: New Born Presented in part to the Society for Pediatric Research, Washington, D. C., May 5, 1983.
$\mathrm{PaO}_{2}(r=-0.60, p<0.001)$. A strong negative correlation between $\mathrm{TxB}_{2}$ and $\mathrm{CO}$ was observed over the first $180 \mathrm{~min}(r=$ $-0.73, p \leq 0.001$ ). There was a statistically significant correlation between $\overline{\mathrm{AoP}}$ and 6-keto-PGF ${ }_{1 \alpha}$ concentration between 60 and $180 \mathrm{~min}(r=-0.54, p<0.002)$. Indomethacin improved the hemodynamic function in this model of GBS sepsis. This improvement was related in part to inhibition of synthesis of thromboxane $A_{2}$ and prostacyclin.

\section{Abbreviations}

GBS, group B streptococci AoP, aortic blood pressure $\mathrm{CO}$, cardiac output

Ppa, pulmonary artery pressure

Ppaw, pulmonary wedge pressure

Pra, right atrial pressure

$\mathbf{T x B}_{2}$, thromboxane $\mathbf{B}_{2}$

Since 1962 when Northover and Sabramanian (18) first used sodium salicylate to treat endotoxin shock in dogs, numerous investigators have documented the beneficial effects of nonsteroidal anti-inflammatory agents on hemodynamics and survival in experimental endotoxin shock $(6-9,14,15,20-22,32)$. These studies have led to further work implicating prostaglandins and thromboxanes in the pathophysiology of endotoxin shock (1-3, 10-12). Particular attention has focused on the roles of thromboxane $\mathrm{A}_{2}$, a vasoconstrictor and platelet-aggregating agent, and prostacyclin, a vasodilator and anti-aggregating agent. 